JOALL (JOURNAL OF APPLIII) LINGUIS'TICS ANIDLITIERA'TURE)

Vol. 5 No. 2, 2020

ISSN (print): 2502-7816; ISSN (online): 2503-524X

Available online at https:// ejournal.unib.ac.id/index.php/joall/index

doi: http:/ / dx.doi.org/10.33369/joall.v5i2.11554

\title{
UTILIZING SENTANI FOLKTALES TO TEACH SPEAKING FOR CHILDREN OF COMMUNAL AGENTS IN JAYAPURA REGENCY, PAPUA
}

\author{
Wigati Yektiningtyas ${ }^{1}$, Juwita Purnamasari Br.Ginting² \\ Department of Language and Art, English Teaching Program, Faculty of Teacher \\ Training and Education, Universitas Cenderawasih, Jayapura ${ }^{1}$; \\ Communal Agents Teacher ${ }^{2}$
}

Corresponding email: wigati_y@yahoo.com

\begin{abstract}
Folktale is one of Sentani people's cultural heritages that is rarely told anymore. As social products that teach knowledge, history and moral values, folktales have to be preserved. In Jayapura Regency, there are some communal agents for children that have various programs and one of them is teaching English. To keep motivating them learning, it needs more interesting and challenging materials. From the research on revitalization of Sentani language for children through folktales in Jayapura Regency in 2017-2018, it was found that children like to listen and read Sentani folktales. Accordingly, this paper aims at utilizing folktales to teach English for children focusing on speaking in some children communal agents in Jayapura Regency by exploring two main questions, i.e. (1) why teaching speaking using Sentani folktales and (2) how to teach speaking using Sentani folktales. This is a qualitativedescriptive study utilizing data of folktales that were obtained via observation, interview, and FGD from some informants, namely tribal chiefs and Sentani elders in East, Central, and West Sentani in 2017. This writing adopts theory of literature and language teaching (Lazar, 2002) and Vigotsky's scaffolding learning (Omrod, 2020). This study concludes that (1) children are more active and enthusiastic to speak in English, (2) children are able to learn their ancestor's heritages, (3) it is an alternative way of both revitalizing Sentani folktales and disseminating the socio-cultural values embedded in them.
\end{abstract}

Keywords: folktales, Sentani, speaking, revitalization

\section{INTRODUCTION}

In the past, Sentani folktales, i.e. legends, myths, fables, and fairy tales were passed down from parents and grandparents to children and grandchildren to teach about history, life strategies, philosophy, socio-culture, and morals. 
According to an ondofolo (the highest tribal chief) of Waena, Ramses Ohee (2017, personal communication/pers.com.), at least there are four types of folktales in Sentani, i.e. (1) taboo - sacred tales that exclusively circulated among ondofolos, (2) folktales that circulated among tribal chiefs, (3) folktales that circulated among adults of certain tribes, and (4) general folktales that commonly circulated (cf. Danandaja, 2002). Except general folktales that can be heard by common people, other three types of tales cannot be heard even accidently by other people or tribes. For example, if somebody from common people on purpose accidently heard a taboo tale, s/he would be cursed. In Sentani expression, s/he got a pelo (mystical curse) in the form of bad luck, sickness, or even death. In the same line, children were not allowed to hear adult tales (Cornelis Modouw, 2013-pers.com; Izak Puhili, 2017-pers.com.).

Korina Ongge and Luni Nere (2018-pers.com.) said that parents and grandparents, usually mother and grandmother told fables or fairytales during their spare time at day time or at night as bedtime stories. After telling tales, they gave the tales' moral lessons too. For example, from a fable entitled "The Sparrow and the Cassowary" that told about an arrogant, tricky, and cruel cassowary who liked to bother other little and weak birds, finally was defeated by a little sparrow (Yektiningtyas-Modouw, 2018). From this fable, children were taught about heroism, bravery, sacrifice and truth. Children were also reminded not to be like cassowary that was always cruel and suppressed weak creatures. From a legend entitled "The Journey of Heram People to Sentani Lake", children were taught about the history of Sentani origins, namely their journey from East Sepik, PNG, heroism, persistence, leadership, and cooperation. From a legend entitled "The Origin of Lake Sentani", children were taught about respect to supreme beings (gods/goddesses), to other people, and to nature as well as the importance of loyalty, patience, and honesty (Yektiningtyas-Modouw, 2017). In short, in the past, folktales were used by Sentani people to spread moral values. This is also in line with the ideas of Arumsari, et.al. (2018), Santyaningtyas and Noor (2016) and Court and Rosenta (2007) about the pedagogical functions of telling folktales (cf. Danandjaja, 2002; Finnegan, 1996). Unfortunately, nowadays tradition of folktales telling is not found anymore. Since Sentani people live in a big town Jayapura as the capital of Papua Province, they are influenced by modernity, technology and heterogeneous people that indirectly or directly distracted their traditional life. They are getting global. Similarly, this phenomenon was also strengthened by Ozlem(2018), Yektiningtyas and Modouw (2017), and Kashima, et.al (2011) who said that globalization change the tradition and social habits. Nowadays children are more interested in watching TV, playing gadgets instead of hanging around with friends playing traditional games, playing hide and seek, or simply 
fishing in the lake or the river. Since the parents do not tell them folktales, then they only know folktales from other places told by their teachers who come from outside of Sentani or Papua. Thus, they acknowledge more folktales like "Bawang Merah dan Bawang Putih" from Central Jawa, "The Origin of Tangkuban Perahu Mountain" from West Jawa, "Malin Kundang" from West Sumatra, "Legend of Lake Toba" from North Sumatera, "Toar and Lumimuut" from North Sulawesi or even "Snow White" and "Cinderella" from abroad. This phenomenon cannot be ignored. As a social product that reflects history, philosophy, mythology, and identity of Sentani people (cf. Swingwood, 1972), Sentani folktales need to be introduced, revitalized, and socialized to young generation. Otherwise, Sentani folktales will extinct and Sentani young generation will lose their heritages, cultural roots, and identities. Interestingly, even though Sentani children did not acknowledge their folktales very well, a previous research on the revitalization of Sentani language for children by using folktales in 20172018 found that Sentani children were enthusiastic to hear their local folktales. This is actually the main milestone of the study. It is true that compared to other folktales from outside of Papua, Sentani folktales are not very popular for Sentani children. Thus the initiation of using them in teaching-learning process will motivate them to know and learn more about their ancestor's cultural heritages and the socio-cultural values implied in them. This strategy is an alternative way to preserve Sentani folktales as well. Hopefully, from the process of learning, the children will know their ancestor's history, knowledge, life principles, local wisdom, and socioculture. This will trigger them to learn more folktales or other Sentani folklore. This is how the preservation simply starts from.

Sentani children's life is not very different from other children in other places of Papua. They have good gross motor skill that makes them very active physically. They cannot remain sitting or staying at home for a long time (Modouw, 2015). They are also very close to nature. On the one end, their being active is very good since they tend to try and do new things. On the other end, if they are not well guided they may be trapped in doing negative things. Some of them are involved in "children criminals". From observation done in 2017-2018in Waena and its surrounding and supported by children watcher and activist, Sara Mebri-Noya and Sari Tumbal (2018 pers.com.), there are many children in the age of 6-14 years old who are involved in stealing and inhaling aica aibon glue. They have to be saved. Gathering them in a communal agent may be used as an alternative way out. These children need scaffolding learning, i.e. learning aid (Vigotsky in Omrod, 2020; Santrok, 2009) to positively make use of their spare time and manage their energy. As social creatures, by having them in a communal agent, they will learn from other children or their teachers. There are some 
communal agents for children in Jayapura Regency that have various programs, i.e. sports, arts, and language learning, especially English. Seeing the facts that Sentani children like folkltales, some communal agents utilize Sentani folktales as alternative materials to teach English, especially speaking. This is also highlighted by (Nhung, 2016 and Lwin, 2015), that folktales have potentials to learn languages.

Speaking has been the most essential skill from other skills of English (Bahadorfar, 2014). Having the ability of speaking English has been required in most aspects in our life nowadays such as economy, tourism, education, health, and others. As stated by Brown and Yule in Bahadorfar (2014) that children will be judged in their real-life situation through their English speaking ability. They will show good impression when they can speak English fluently. Thus, it is important for teachers to equip children in having this ability. Actually, it is good to teach English for children since young learner, so they can get the opportunity to compete globally, obtain better education and job. Unfortunately, in the newest curriculum, English is not a compulsory subject for elementary school (Ahmad, 2014). Now it is a local content or elective subject. This condition causes a lack of children English environment to practice their English at schools while in fact Sentani children like to talk but their English-speaking skill is still low. It is because they still deal with some speaking problems. For instance, a lack of vocabulary mastery, confidence, opportunity to speak English, and the crucial one is the English environment. Hence, communal agents can play a vital role in enhancing their speaking skill by providing a place for them to practice their English more and to obtain English knowledge.

This paper specifically discusses the benefits of utilizing folktales in learning speaking for children in communal agents. The authors focus on three communal agents, i.e. Waena (established in 2015), Asei Island (established in 2014) and Kampung Harapan (established in 2019). Speaking skill is prioritized due to the facts that Sentani children are very active and like to talk. Besides, as tourist destination, children - as the continuation of Sentani generation -have to be trained to communicate to tourists, especially as tour guides and souvenirs sellers (bark paintings and carvings). In short, this paper focuses at exploring (1) why teaching speaking using Sentani folktales and (2) how to teach speaking using Sentani folktales. Hopefully, by having these strategies, Sentani children are able to speak English, use their time positively as well as acknowledge and proud of their ancestor's cultural heritage.

\section{METHODS}

This writing is a development of a multiyear research entitled "The Revitalization of Sentani Language for Children by Using Folktales" funded 
by the Ministry of Research, Technology and Higher Education of Republic of Indonesia in 2017-2018. Data of folktales were collected from some informants, namely tribal chiefs and Sentani elders in East (Waena and Asei Island), Central (Ifale and Hobong), and West Sentani (Doyo Baru and Kwadeware) in 2017 via observation and interview. The folktales obtained that were told in Papuan Malay and sometimes inserted with some Sentani terminologies and words were then rewritten in Indonesian. The results were then discussed with the tribal chiefs before they were converted into "children folktales" - tales that used simpler language that could easily be followed by children and finally translated into English. To avoid some taboos and myths that cannot be publically circulated, this writing only focuses on two fables, i.e. "Ebi and Kandei" and "The Sparrow and the Cassowary" as well as two legends "The Origin of Abepura Town's Name" and "The Journey of Heram People to Sentani Lake".

Focus Group Discussion (FGD) was attended by tribal chiefs, Sentani elders, Sentani linguists, representatives of English teachers, representative children from communal agents was conducted to check the folktales accuracy and the translation, the folktales used in English teaching-learning process, and the folktales' socio-cultural background. There are some reasons of choosing three communal agents in Waena, Asei Island, and Kampung Harapan. Firstly, English is given in these three communal agents. Secondly, since there are foreign tourists come to Asei Island to buy Sentani souvenirs: bark paintings (malo) and carving, English is needed to help them (children and parents) in communicating with tourists. Bark painters from Asei Island, namely Marthen Ohee, Agus Ongge, and Corry Ohee (2018pers.com.) said that due to the language limitation, they cannot explain various things to tourists. It has been frustrating time for them to communicate to the tourists while there are lots of tradition, arts, and history that can be shown off in the island. This writing adopts theory of Lazar (2002) on the benefits of using literature in learning language and Vigotsky's theory on scaffolding learning (in Omrod, 2020) that strengthens about the possibilities of children to learn more by having challenging materials.

\section{FINDINGS}

\section{Why Teaching Speaking Using Sentani Folktales?}

Speaking has been a vital skill in learning English especially for young learners. Having good communication skill since earlier age, can be a good thing for them in social life. It is also in line with $\mathrm{K} 13$ and $21^{\text {st }}$ century skills which include communication ability that every child should have. In teaching speaking to young learners, folktales can be utilized as a learning media. Firstly, it is because children do not need to think hard and feel alienated from the folktales since the setting of the folktales is around them. 
They feel like they own the story. Some children, to name some, i.e. Caroline Ongge (10 years), Daniel Ohee (11 years), Sarah Pepuho (13 years), and Gevan Ongge (13 years) (pers.com, 2019) said that hearing Sentani folktales was like hearing and feeling about themselves: their life, their land, their sky, their air, their lake, their river, their forest, their fauna, their flora, and their traditional objects, like canoes and houses. Lazar (2002) describes the children's feeling as "emotional ties" between them and the folktales they have heard (cf. Dixit, 2017). In this time, Sentani folktales were employed in teaching speaking to Sentani children at the age of 10-14. Secondly, speaking skill is chosen in this learning, as it was previously stated, due to the fact that Sentani children are active and like to talk (cf. Modouw, 2013). They are not happy to be silent in class. Thirdly, it is also noteworthy that since Sentani's consonant and vowels of Sentani language have similar sounds as in English, the children are happy and easy to pronounce some English words. Compared to Sentani children who only speak Indonesian, Sentani children who speak both Indonesian and Sentani are easier to pronounce some words like "sparrow" [spærow], "cassowary" [kæsa'werie], because there is an /æ/ sound in Sentani and "remember" [rImembər], and"tribe" [traIb] because there is an [ I ] sound in Sentani and "jungle" ['dz^ng(ə)1] since there is an /ə/ sound in Sentani as well. Similarly, Sentani children are helped in pronouncing some English words like "that" [ðæt] and"dancing clothes" ['da:nsinkləひðz], since there is a /ð/sound in Sentani, "north" [no:(r) $\theta$ ] since there is a / $\theta$ / sound in Sentani too (Hartzler, 1992; Cowan, 1965).

\section{The Implementation of Sentani Folktales in Teaching Speaking}

The authors as the teachers in communal agents as well utilized two fables and two legends to teach speaking for children in two different levels. They are lower level (10-12 years old) and higher level (13-14 years old). Hence, there were two different activities applied. The authors only focused on vocabulary building and producing simple sentences for the lower level while for the higher level, they offered more challenging activities.

\section{Lower Level of Group (Vocabulary Building)}

Firstly, some questions were addressed to the children about folktales they know. Some of them mentioned several titles such as "Ebi and Kandei", "The Cassowary and The Sparrow", "Cinderella", "Bawang Merah Bawang Putih", "The Legend of Toba Lake" and other titles that they might find on TV or on their school text books. This activity was done to guide the students to the lesson. The teachers told the students that there were some stories happened around their place in Sentani Lake such as "Ebi and Kandei" and "The Cassowary and the Sparrow" as they said. We then asked 
the students about what they can find around Sentani Lake. Next, the students were instructed to write things they can see around there. Most of them could not write them in English so they were allowed to write the things in Indonesian. The students wrote the words enthusiastically. It was proved by the total of words they could write. The teachers said that on that day, they would learn about some words they had written.

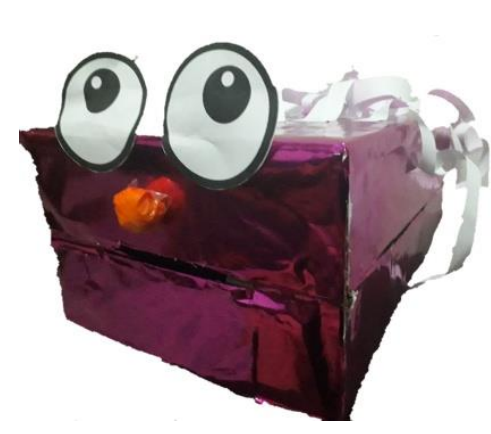

Picture 1: Monster Box (Flashcard/Pers.Doc)

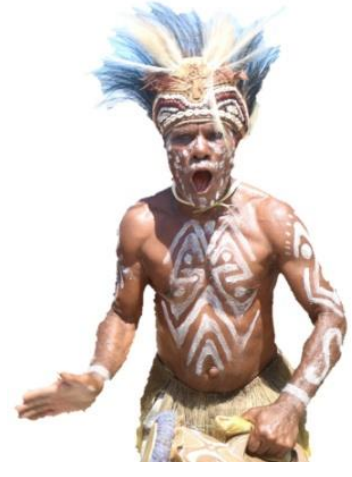

Picture 2: Body Painting (Flashcard/Pers.Doc)

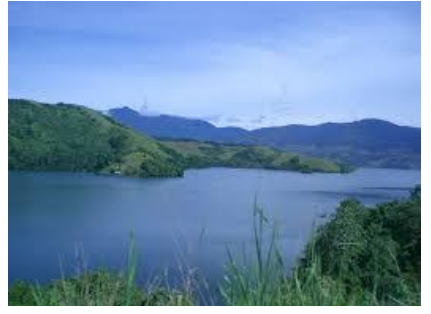

Picture 3: Lake (Flashcard/ www.google.com/ danau_sentani)

We then took a legend entitled "The Journey of Heram People to Sentani Lake". Some students started to show their enthusiasm when they heard the title. It was because the words "Heram" and "Sentani Lake" sounded familiar with them. In other words, the children had emotional ties with the story as it was also concluded by Dixit, et. al. (2017) and Lwin (2015) in their studies on the use of folktales in language learning. It is a good approach to attract children's attention. Media should attract the students' attention to make the teaching and learning process more interesting (Oroujlou, 2012). Before come into the text, we did vocabulary building to equip the students in comprehending the story in English language. Thus, the students have got prior knowledge before going to a higher-level material (Lisa, 2019; Arumsari, et.al. 2019).

There were 10 flashcards taken from the story of "The Journey of Heram People to Sentani Lake" provided (Picture 2-3). They were put in a monster box the authors brought (Picture 1). Flashcards were used because children around their age or in level of elementary most use their sense of sight. Hence, pictures could be helpful for them in visualizing new words (Lisa, 2019). Firstly, the monster box was introduced to the children using TPR method. The authors would chant the same sentences for two or three times while doing some body movements. Repetition of the same phrases for many times will lead the learners to master the language (Kartikasari, 2012). It is in line with Larson-Freeman in Kartikasari “language learning is a 
process of habit formation. The more often something repeated, the stronger the habit and the greater learning. Learning a foreign language is the same as the acquisition of the native language" (cf. Vigotsky in Omrod 2020). As Asher said in Putri (2016), in TPR the children can listen, watch, and imitate the teacher for several times. These steps can be beneficial for the children to give them much time to be more ready before speaking. "It's a monster box, rah rah, monster box rah rah, monster box rah rah". Seeing the teachers did this, the children started to smile and laugh. To engage them, they were asked to chant together. "What's in the box? Knock - knock. What's in the box? Knock - knock". From this activity, the students kept showing their enthusiasm. All of the students followed to chant and imitate the teachers' movement. Since children have greater energy than adult, learning activity which involves body movements will be a fun activity to do to spend their energy. Then, one child was asked to the middle and took a flashcard from the box. S/ he was helped to lift off the lid of the box by one of the teachers. As the child reached his/her hand in, the teacher pretended the monster box was trying to eat his/her hand. The children started to laugh. Then, the child tried to take the card again and gave it to her. Next, she looked at the card with enthusiasm and asked the children if they would like to see. Then the teachers had the class chant together. "Let me see, please. Let me see, please. Let me see, please". She revealed the flashcard and introduced the new word using TPR. "It's a lake, woooooof. It's a lake, wooof. It's a lake, wooooof". Then she placed the flashcard (Picture 3) in front of her and had the whole children chant again "what's in the box?" and others. The class was noisy. They finished all the vocabularies.

As they finished the ten flashcards, the teachers did more repetition. They asked the children to help them put the flashcards in to the box. Their friendly monster box pretended to be starving. Hence, they needed to feed it. A flashcard was chosen by the teachers and had the children chant together. "Where is the lake? Where is the lake? Where is the lake?" After that, a child was pointed to come to the front and found the flashcard. One of the teachers asked the student one more time "Where is the lake?". She guided the child to the correct flashcard. The child then tapped the card and said "Here is the lake. Here is the lake. Here is the lake" after getting a model from the teacher. They picked up the flashcard and fed it to the monster box. They did the same thing until the flashcard had been fed to the monster box. In this activity, children also showed their confidence in chanting and acting out them.

The children were split into 3 groups. In $21^{\text {st }}$ century education, there are several skills integrated. They are knowledge, psychomotor, affective, and information, communication, and technology skill. Collaboration is one of $21^{\text {st }}$ century skills in knowledge that every child should have. There are 4 
skills in $21^{\text {st }}$ century skills of knowledge and they have been integrated in K13. They are critical thinking, creativity, communication, and collaboration. As Greenstein said in Rendhana that collaboration skill, on the one hand, is children's capability to work together, respect diversity in a team, and train children in taking a decision to reach the group's goal. On the other hand, collaboration is also a good opportunity for children to learn from their friends: to imitate the correct ones or to avoid the same mistakes. Vigotsky in Omrod (2020) calls that as a scaffolding where students can learn from both friends and teachers. Then, 10 flashcards contained of pictures and words taken from 3 different Sentani Folktales namely "The Origin of Abepura's Name", "Ebi and Kandei", and "The Sparrow and the Cassowary" were given to each group. The students were asked to match the pictures with the correct words in group. The teachers did mobilization to check the children's work. Then, one member from each group was asked to be the leader. The leader acted out as a teacher to lead the member of their group to review the vocabulary they got as they did together before. The teachers moved from one group to other groups to observe the children's activity. At the end of the meeting, the children got feedback about the lesson. They were excited about the lesson. They still chant after the class ended. It proves that repetition can help children to make the language to be their habit. Accordingly, in teaching speaking teacher should give more opportunity to the students to more watch, more listen, and more imitate. It is because learning a foreign language is as the same as when they acquired their mother tongue (Putri, 2016).

To make sure that all the children get the same vocabularies, the teachers employed Think Pair Share method on the following meeting. Each group visited others groups. The leader of each group stayed in the group. The members of each group were spread to other groups to collect the vocabularies from other groups. After that, all members went back to their groups and shared the new vocabularies they got from other groups. Next, the children and the teachers played guessing words. They got an example about the game from the teachers. They had to give some clues and others should guess the words. "It can fly. It is from Papua" then the students shouted "Bird of Paradise". The children did this in turn using the vocabularies they learned. They only gave simple sentence or they could use gestures if they got stuck. 


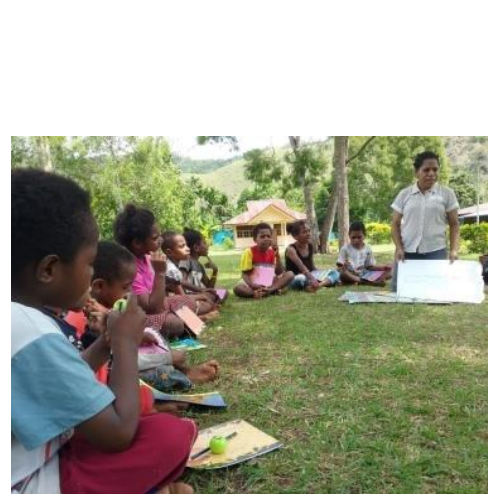

Picture 4: Lower Level of Children (Pers. Doc.)

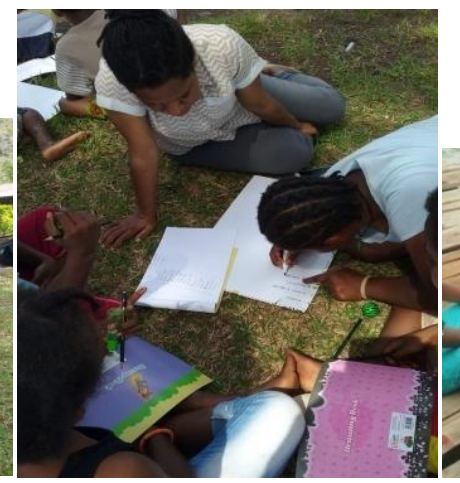

Picture 5: Children and teachers are doing brainstorming discussing about folktales (Pers.Doc)

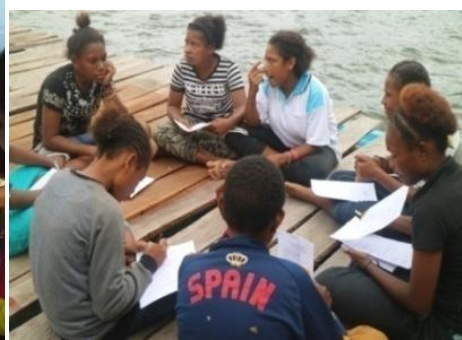

Picture 6: Higher Level of Children (Pers.Doc)

\section{Higher Level of Students}

Higher level children were for children at the age of 13-14 (Picture 6). In this group, more challenging activities were given. Firstly, they were split into 4 groups. Each group contained of 4 children. Then, each group got a different worksheet and flashcards. They got different stories and different vocabularies. To build their vocabulary, the children had to match the 10 flashcards given with their English words. They might consult the meaning to dictionary in order to check the meaning. They got 5 minutes to complete activity 1. Most of the children looked enthusiasm when they saw the pictures of tribal chief, bird of paradise, body painting (Picture 2), and some more words. It made them excited to check the meaning of the words they could find in their surroundings. It can be assumed that teaching vocabulary of the things around the children's environment will be interesting for them. It is because the children will find it easier to illustrate the words. The teachers visited each group to check their work. Then, the children were asked to present the vocabularies they got to their friends. The teachers taught them how to open and close their presentation. "To open and to close your presentation, you may use this template: Good afternoon every one. Thanks for the chance that is given to us. In this time, we are going to present ten vocabularies we got from the story of "The Sparrow and the Cassowary" (the title of your story). So, without further ado, let's get started. Present your flashcards. To end your presentation, you may say "Okay, we think that is all about our presentation. Thank you". All children should speak. Consequently, the children had to divide their presentation part for each of them. It was to give everyone time to practice and build their confidence to speak in front of people. They showed the flashcards they got to their friends and pronounced each word. In this activity, the children still made several mistakes in pronouncing some words because those were new vocabularies for most of them. The teachers 
corrected their pronunciation at the end of all presentations. They said the words and the children repeated them. This is in line with Vigotsky's theory on scaffolding learning (Omrod, 2020; Van de Pol, 2015). It is interesting to see how students learned quickly from the teachers and also from their friends' presentation. They imitated their friends' correct pronunciation and avoid doing the same mistakes.

For the next activity, the students were instructed to see their stories. Next, they were asked to do several questions in the worksheet given. Think Pair Square Share (TPSS) method was employed in this activity. A group consisted of four children. They were given same stories with several questions. Firstly, each child had to do all the questions alone. It was done to build students' critical thinking. In this step, some children found difficulties in answering the questions since they had limited English knowledge and they did not have friends to share with. After 15 minutes, the teachers instructed them to discuss their answers with their pair. They might find different answers here since they might have different point of view. In this step, the class started to be noisy. They discussed their answer with a pair. They were also warned to use English as much as they could. Some children who were still hard to answer the questions in the previous step seemed to be more excited here. They got enrichment from their pair in answering the question. Then, the children were asked to share their answers with their two other friends in the same team.

\section{DISCUSSION}

Utilizing folktales to teach speaking due to the fact that as the future generation of Sentani people, children do not recognize their own folktales. Ramses Ohee (Waena tribal chief) and Enos Deda (Ayapo tribal chief), and Origenes Monim (the Head of Hobong Customary School) (2019-personal communication) said that Sentani children need to (re)learn their ancestor's cultural heritages, including folktales. Their worries are also strengthened by some parents and teachers (2019-pers.com) who complained that their children and students prefer to read or listen to folktales from outside of Sentani. Ironically, some of Sentani children also said they never have opportunities to hear Sentani folktales both from their parents and teachers (pers.com-2019). As the future generation of Sentani people who will continue the tradition, identity, and cultural heritages, Sentani children need help to find their whole life and identity. Similarly, this is also in line with Shehada (2020) and Folley (1986) that pointed out the importance of understanding cultural heritages and identity for children as the continuation of a certain generation. 
By utilizing two fables and two legends to teach speaking for children in two different levels, i.e. lower level (10-12 years old) and higher level (1314 years old), it can be seen the interesting class atmosphere. Vocabulary building and producing simple sentences for the lower level encouraged the children to find new vacabularies and create various simple sentences. While challenging activities given to higher, i.e. presenting ideas in front small and bigger groups by answering guided questions made them to develop their confidence. Children started to show their confidence in sharing their ideas. It was because they obtained more knowledge from their previous pair. After discussing their answers, they made conclusion for the story based on the guiding questions given. In these activities, students were asked to speak actively. They spoke in a smaller group with their pair and went to a larger group with two other friends in the same team. It is believed that this model can help the students to build their confidence in speaking (Rufiana, 2017). This model of teaching strategy is good for children. They are trained to speak in a smaller group. Thus, when they are asked to speak in a larger group, they can be more confident since they have got insight or prior knowledge from the previous discussion in a smaller group. Finally, all the teams were asked to present about the story they got in front of the class. They had to divide their time of speaking, so everyone in the team spoke. Children showed their confidence in presenting the story.

Sentani children are active. It was proved by their enthusiasm in imitating the teacher's pronunciation and action. Most of them have good pronunciation. It is because Sentani language has some identical sounds as English. They did not find it hard in pronouncing 'th' sound as in the word "traditional clothes" or the "schwa" sound as in the words "bird of paradise and island". Although most of Sentani children are not using Sentani language actively (Origenes Monim, 2019-pers.com), they get exposure about the language from their parents who still speak the language. Utilizing folktales in learning English has many benefits. For instance, when they learned words such as "tribal chief", "arrow", "bow", and "bird of paradise" they could simply imagine the real things since they can find it in their environment. Furthermore, the children could easily relate the words as "body paintings", "dancing clothes", "traditional feast", and "lake" to their daily life when they had traditional feast around Sentani Lake and they can find dancer with dancing clothes and body paintings (cf. Lazar's theory on emotional ties between the learners and the folktales). This study also underlines that vocabularies building from folktales of "their own" before going into the story helps the children much in comprehending the story. This kind of contextual learning is strongly strengthened by K-13. Learning speaking by using folktales do not only help the children in learning 
speaking but also enhance their knowledge about their own identity and their ancestor's cultural heritages (Yektiningtyas and Modouw, 2017).

\section{CONCLUSION AND SUGGESTION}

Sentani people are lucky to be blessed with various cultural heritages that unfortunately are not recognized by young people. By utilizing folktales as English learning materials in some communal agents in Jayapura Regency, it implies two things, i.e. teaching language and socializing Sentani folktales and some socio-cultural embedded. As learning materials, it is found that (1) children are enthusiastic in following the lesson when the material comes from their surroundings such as Sentani folktales, (2) folktales can be used in teaching speaking skill, (3) building up children's vocabulary needs to do before instructing children to speak or to do more complicated activities, (4) Total Physical Response (TPR) can be a good method in teaching speaking for young learners while for higher level of children, a challenging activity can be given. Thus, Think Pair Square Share (TPSS) is good to apply in equipping children in addressing the challenge such as speaking in a larger group confidently. From those all activities, children can also get some scaffolding by learning from other friends or teacher to improve their vocabularies and language proficiency. As media of socializing Sentani folktales, it is concluded that (1) children find their identity and love their ancestor's cultural heritages, (2) they become agents who are enthusiastic to disseminate their tales to their friends, (3) moral values from the folktales can be taken for guiding the children in running their social life. Bringing folktales to a classroom can be an alternative both in teaching language and culture. However, a teacher should ensure that the content of the folktales is suitable with the children. Moreover, in applying a teaching method, children's English proficiency, age, needs, and the total of the children in a classroom need to be considered. All in all, using Sentani folktales in teaching-learning process enhances both children's English language and socio-cultural proficiency.

\section{REFERENCES}

Ahmad, S. (2014). Problematika Kurikulum 2013 Dan Kepemimpinan Instruksional Kepala Sekolah. 8(2), 98-108. https://doi.org/10.13170/jp.8.2.2158

Arumsari, A. D., Arifin, B., \& Rusnalasari, Z. D. (2017). Pembelajaran Bahasa Inggris pada Anak Usia Dini di Kec Sukolilo Surabaya. Jurnal PGPAUD Trunojoyo : Jurnal Pendidikan Dan Pembelajaran Anak Usia Dini, 4(2), 133. https://doi.org/10.21107/jpgpaud.v4i2.3575

Bahadorfar, M., \& Omidvar, R. (2014). Technology in Teaching Speaking Skill. International Journal of Multidisciplinary Research Review, 2, 9-13. 
Court, D., \& Rosental, E. (2007). Values Embodied in Children's Literature used in Early Childhood Education in Israeli State Schools. Early Childhood Education Journal, 34, 407-414. https://doi.org/10.1007/s10643-006-0140-9

Cowan, H. K. (1965). Grammar of the Sentani Language. With Specimen Texts and Vocabulary. [With a Map.]. Martinus Nijhoff. https://books.google.co.id/books?id=dGSElwEACAAJ

Danandjaja, J. (2002). Folklor Indonesia: Ilmu Gosip, Dongeng dan lain-lain. Pustaka Utama Grafiti. https://books.google.co.id/books?id=dtciAAAAMAAJ

Dixit, V., Kaur, G., \& Shanwal, V. K. (2017). Emotional Intelligence in Indian Folklore. 4(1), 1-8.

Dundes, A. (1980). Interpreting Folklore. Indiana University Press.

Finnegan, R. (2003). Oral Traditions and the Verbal Arts: A Guide to Research Practices. Oral Traditions and the Verbal Arts: A Guide to Research Practices, 1-270. https://doi.org/10.4324/9780203393215

Foley, J. M. (1986). Oral Tradition in Literature: Interpretation in Context. University of Missouri Press.

Hartzler, M. (1992). A Brief Phonology of the Sentani. In Afeu: Vol. year III (Issue 4). Percetakan Universitas Cendrawasih.

Hartzler, M. (1992). A Brief Phonology of the Sentani. In Afeu: Vol. year IV (Issue 4). Percetakan Universitas Cendrawasih.

Kartikasari, E., Arifin, Z., \& Salam, U. (2015). Improving Students' Speaking Ability Through Repetition Drill. Jurnal Pendidikan Dan Pembelajaran Untan, 4(1).

Kashima, Y., Shi, J., Tsuchiya, K., Kashima, E., Cheng, S., Chao, M., \& Shin, S.-H. (2011). Globalization and Folk Theory of Social Change: How Globalization Relates to Societal Perceptions about the Past and Future. Journal of Social Issues, 67, 696-715. https://doi.org/10.1111/j.1540-4560.2011.01723.x

Kemendikbud. (2016). Kurikulum 2013: Kompetensi Dasar Sekolah Dasar/Madrasah Ibtidaiyah.

Laurenson, D., \& Swingewood, A. (1972). The Sociology of Literature. MacGibbon and Kee. https:/ / books.google.co.id/books?id=1z4HAQAAIAAJ

Lazar, G. (2002). Literature and Language Teaching: A Guide for and Trainers. Cambridge University Press.

Lisa, H. (2019). the Effectiveness of Flashcards on the Motivation to Increase English Vocabulary Among the Fourth Elementary School. JOALL (Journal of Applied Linguistics \& Literature), 4(1), 43-53.

https://doi.org/10.33369/joall.v4i1.6852 
Utilizing Sentani Folktales to Teach Speaking for Children of Communal...

Lwin, S. M. (2015). Using folktales for language teaching. The English Teacher, $44(2), 74-83$.

Modouw, J. (2013). Pendidikan dan Peradaban Papua: Suatu Tinjauan Kritis. Bajawa Press.

Muhammad, J. (2019). Eksplorasi Nilai Fabel Sebagai Sarana Alternatif Edukasi Siswa. Jurnal Pendidikan Bahasa Dan Sastra, 18, 294-303. https://doi.org/10.17509/bs_jpbsp.v18i2.15517

Nhung, P. T. H. (2016). Folktales as a Valuable Rich Cultural and Linguistic Resource to Teach a Foreign Language to Young Learners. The Journal of Education, Culture, and Society, 1, 23-28.

Ormrod, J. (2003). Educational Psychology: Developing Learners.

Oroujlou, N. (2012). The Importance of Media in Foreign Language Learning. Procedia - Social and Behavioral Sciences, 51, 24-28. https://doi.org/10.1016/j.sbspro.2012.08.113

Özlem, A. (2018). Importance of "Cultural Heritage and Conservation" Concept in the Architectural Education. Journal of Human Sciences, 15, 1700-1710. https:// doi.org/10.14687/jhs.v15i3.5380

Pol, J., Volman, M., Oort, F., \& Beishuizen, J. (2015). The effects of scaffolding in the classroom: support contingency and student independent working time in relation to student achievement, task effort and appreciation of support. Instructional Science, 43, 615-641.

Putri, A. R. (2016). Teaching English for Young Learners Using a Total Physical Response (Tpr) Method. Jurnal Edulingua, 3(2), 16-22.

Redhana, I. W. (2019). Mengembangkan Keterampilan Abad Ke-21 Dalam Pembelajaran Kimia. Jurnal Inovasi Pendidikan Kimia, 13(1), 2239-2253.

Rufiana, D., \& Mulyadi, M. (2018). Using Think-Pair-Square-Share Strategy to Improve Students' Speaking Ability for Indonesian Senior High School Students. JOALL (Journal of Applied Linguistics and Literature), 2, 83-93. https:// doi.org/10.33369/joall.v2i1.5872

Santrock, J. (2008). Educational Psychology. McGraw-Hill Companies, Incorporated. https://books.google.co.id/books?id=18wxPwAACAAJ

Santyaningtyas, A. C., \& Noor, M. Z. M. (2016). Preserving of traditional culture expression in Indonesia. Asian Social Science, 12(7), 59-65. https://doi.org/10.5539/ass.v12n7p59

Shehada, Z. M. (2020). Understanding the Conservation of Cultural Heritage: Contextual Interpretation Based on USA Case Study. International Journal of Cultural Heritage, 5, 11-22.

Yektiningtyas-Modouw, W. (2018). Ebi dan Kandei (Cerita Rakyat dalam Tiga Bahasa: Indonesia, Sentani, Inggris). UNY Press. 
Wigati Yektiningtyas; Juwita Purnamasari Br.Ginting

Yektiningtyas-Modouw, W. (2018). Perjalanan Masyarakat Heram ke Pulau Asei (Cerita Rakyat dalam Tiga Bahasa: Indonesia, Sentani, Inggris). UNY Press.

Yektiningtyas-Modouw, W. (2018). Asal Mula Nama Kota Abepura (Cerita Rakyat dalam Tiga Bahasa: Indonesia, Sentani, Inggris). UNY Press.

Yektiningtyas-Modouw, W. (2018). Burung Pipit dan Kasuari (Cerita Rakyat dalam Tiga Bahasa: Indonesia, Sentani, Inggris). UNY Press.

Yektiningtyas-Modouw, W., \& Modouw, J. (2017). Infusing Culture in English Learning: An Attempt to Preserve Cultural Heritages in Jayapura Municipality, Papua. Language and Language Teaching Journal, 20(01), 40-48. https:// doi.org/10.24071/1lt.2017.200105

Yektiningtyas-Modouw, W., \& Rafra, P. (2017). The Importance of Rewriting Papuan Folktales for Children. Proceeding of 4th LSC: Children's Literature in Southeast Asia. 